
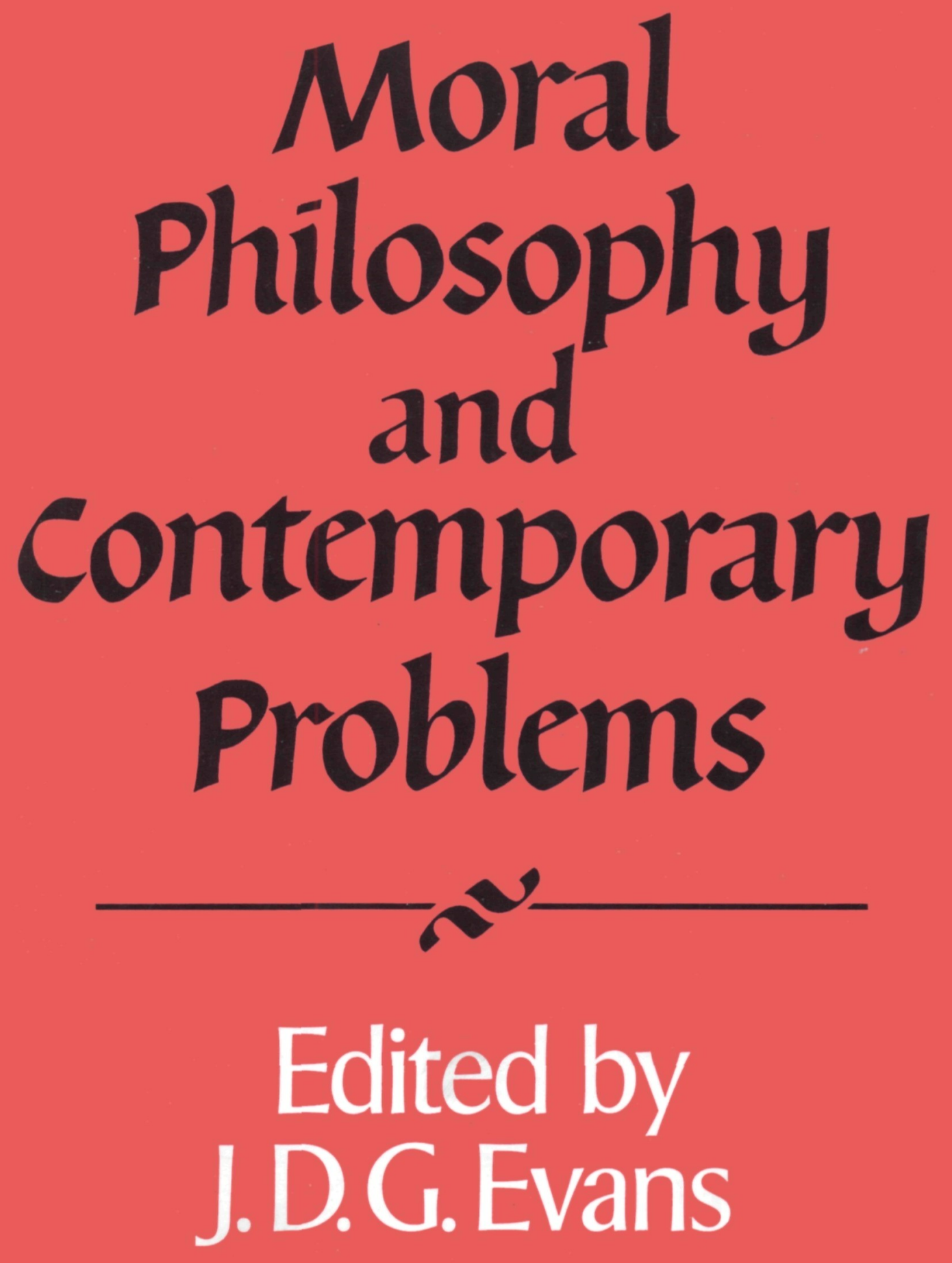


\section{Moral Philosophy and}

\section{Contemporary Problems}

EDITED BY

J. D. G. Evans

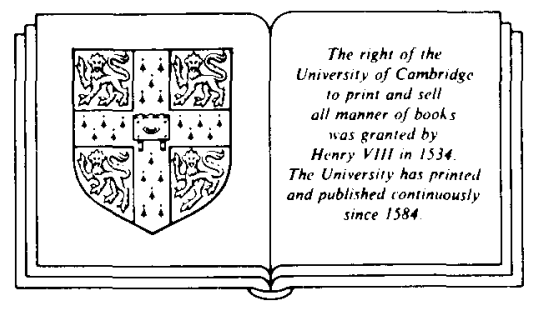

CAMBRIDGE UNIVERSITY PRESS

CAMBRIDGE NEW YORK

NEW ROCHELLE MELBOURNE SYDNEY 
Published by the Press Syndicate of the University of Cambridge The Pitt Building, Trumpington Street, Cambridge, CB2 1RP

32 East 57th Street, New York, NY 10022, USA

10 Stamford Road, Oakleigh, Melbourne 3166, Australia

(C) The Royal Institute of Philosophy 1987

Library of Congress catalogue card number: 88-9509

\section{British Library Cataloguing in Publication Data}

Moral philosophy and contemporary problems.

- (Royal Institute of Philosophy lecture

series: 22 ).

1. Social ethics.

I. Evans, J.D.G. (John David Gemmell), 1942170

ISBN 0-521-35736-5

\section{Library of Congress Cataloguing in Publication Data}

Moral philosophy and contemporary problems/edited by J. D. G.

Evans. p. cm.-(Royal Institute of Philosophy lecture series: 22)

"Supplement to Philosophy 1987."

Bibliography: $p$.

ISBN 0-521-35736-5

1. Ethics. 2. Social ethics. I. Evans, J. D. G.

(John David Gemmill), 1942- . II. Philosophy. 1987 (Supplement) III. Series: Royal Institute of Philosophy lectures; v. 22.
BJ1012.M6343 1988
$170-\mathrm{dc} 19$
$88-9509$
CIP

ISBN 0521357365 (pbk.)

Printed and bound by

Adlard $\tilde{\sigma}$ Son Limited,

Leatherhead, Surrey, and Letchworth, Hertfordshire 


\section{Contents}

Introduction vii

Morality, Individuals and Collectives 1 KEITH GRAHAM

The Marxist Ethic of Self-realization: Individuality and

Community

DAVID ARCHARD

Abstract Morality, Concrete Cases

STEPHEN R. L. CLARK

Abstraction, Idealization and Ideology in Ethics

ONORA O'NEILL

Philosophical Confidence

J. L. GORMAN

On Applying Ethics

JAMES M. BROWN

Philosophy in the Nuclear Age

BARRIE PASKINS

Justice, Exploitation and the End of Morality

ALAN RYAN

Acting According to Conscience

DESMOND M. CLARKE

Leisure

ELIZABETH TELFER

The Right to Work

BERNARD CULLEN

Surrogacy, Liberal Individualism and the Moral

Climate

BOB BRECHER

Ethics and Drug Testing in Human Beings 


\section{Contents}

Genetic Engineering and the Autonomous Individual SHYLI KARIN-FRANK

Brain Death and Brainstem Death: Philosophical and Ethical Considerations

DAVID LAMB

Bibliographical Index

Notes on Contributors 
To the memory of Anna 